\title{
Study on Listing Financing Distribution of GEM Companies and Influence Factors
}

\author{
Fei Wang \\ Ph. D, School of Economics and Management, Beihang University, Xueyuan Road No.37,HaiDian \\ District, Beijing The People's Republic of China \\ warmfine@126.com
}

Keywords: GEM listed company; IPO financing; Technology and research input

\begin{abstract}
Economic structural adjustment is a major topic that concerns the development of China in fairly long future. The growth of high-tech enterprises, an important force in the economic transition of China in the future, is affected by the limitation of financing to a great extent. Ever since it was launched, GEM (Growth Enterprise Market) has assumed the historic mission of implementing the strategy of "driving the development with innovation" and "cultivating strategic emerging industries". This paper uses a sample of a few GEM companies and data revealed before and after they were listed and evaluates the influence factors on GEM companies' financing capacity based on comprehensive indexes as their regional distribution, business type, technological innovative ability, enterprise scale and business development. The findings benefit the objective understanding of financing of GEM listed companies and can be used in the prediction of their future development.
\end{abstract}

\section{Introduction}

Small and medium new high-tech enterprises are an important force in the structural transformation of Chinese economy. However, the financing inefficiency of SMEs, with a great discrepancy between the financing support they can get and their economic role, has been a big problem in the current economic conditions. Financing inefficiency is also one of the major constraints against the development of new high-tech enterprises. Berger et al. [1](2007) proposed that bank loans are the most important in all financing sources of SMEs. But most Chinese commercial banks use security guarantees in credit capacity assessment. It is appropriate for large and medium-sized state-owned enterprise, whereas SMEs has weaknesses in offering security guarantees, which has, to a large extent, hindered SEMs from getting sufficient credit support [2](Xu and Lee, 2009). After the launching of GEM, more and more high-tech enterprises have chosen to finance by getting listed on GEM. Li Yanghui [3]suggested (2008) that high-tech enterprises have to use GEM as the new channel of financing and venture capital withdrawal owing to the their particularities. Chinese GEM, mainly providing a security exchange market with financing channels and room to grow to SMEs and high-tech enterprises which are not able to be listed on the main board, is an important supplement of the main board market and plays a role in the capital market.

Many domestic and foreign scholars have focused on the financing capacity of SMEs in recent years. A few of them take the macro-economic environment into account and integrate internal and external factors to give an overall consideration of the influence factors on enterprise development. For instance, Demsetz [4] suggested that different external environment lead to different equity financing structures of enterprises; in the study on the relationship between financing structure and financial performance, RamiZeitun et al. [5] found that the financing structures of 167 Jordanian companies were significantly negatively correlated to their financial performances, and the companies' business performances were affected by the macro-environment. As for domestic scholars, Sun Linjie and Sun Linzhao [6] carried out the analytic hierarchy process and found that the R\&D ability, financial status and other factors are the primary influence factors on enterprise's financing capacity. There are few domestic studies on the listing financing of technology-based enterprises. Huang Junhui and Wang Wanchen [7] (2000) conducted a comprehensive study on the 
listing of entrepreneurial enterprises from the perspective of venture capital and realized that the listing of technological-innovative enterprises is an effective channel of venture capital withdrawal. Similarly, as research continues, there have been fierce disagreements among domestic and foreign scholars over the acceleration of venture capital on enterprise's technological innovation, represented by the theory of repressive venture capital and neutral venture capital.

\section{Theoretical Analysis and Financing Status}

As the biggest beneficiary of the structural transformation of the economy, GEM has advanced rapidly these years. The exploration of domestic and foreign scholars on listing financing influencing factors and financing capacity has laid an important research basis for this paper.

Theoretical Analysis. American scholar Ronald Gilson [8] (1998) believed venture investment is the most important channel for the financing of high-tech industry in the US. He pointed out that three factors, capital, financial intermediary and company, should be considered based on the conditions of the country in order to establish a perfect venture capital market to provide financial channels for the high-tech industry. Generally speaking, a company needs two external financing conditions. Tobin's Q represents the investment opportunity of the company which can reflect the investment value of the company at a certain level. Under the same conditions, a higher $\mathrm{Q}$ value means a higher investment value. The enterprise can gather more fund to invest. Therefore, the larger the Q value, the more external financing the enterprise has. In international studies, Tobin's Q has already become a common proxy variable for the investment value of enterprises (Adam and Goyal, 2008)[9]. Although the development of stock market in China is not perfect and the market value estimates for Chinese listed companies are not very accurate, many scholars still use Tobin's $\mathrm{Q}$ as the investment value, expected result of company development or measurement of company performance $\mathrm{Su}[10](2005)$; Zhang and $\mathrm{Li}[11](2005)$. However, there are many factors that affect the size of financing capability. Studies on this aspect are relatively mature. Wang Hecheng and Meng Yanfen[12] (2004) demonstrated the importance of financial capacity in the competence system from the perspective of enterprise competitive advantage. Zheng Xiujie and Dong Liying [13] (2006) considered financing capacity as an important composition of enterprise competence system and analyzed the different models of financing capacity of Chinese domestic enterprises in varied stages. They believed that influence factors on enterprise financing capacity include capital structure, volatility of earnings, asset structure, profitability, enterprise scale, opportunity of company growth, etc.

This paper selects twenty-five indexes from eight dimensionalities-including enterprise's profitability, earnings quality, asset structure, growth ability, debt paying ability, operation ability, shareholder structure and technological innovative ability, to comprehensively show the overall situation of company's business and innovation performance influencing the corporate financing capacity before it is listed. Then the correlation between these indexes and enterprise's IPO financing capacity is analyzed. This paper puts forward hypothesis:

Hypothesis: Enterprise's IPO financing is positively correlated to its business performance and innovative ability.

Financing Status and Distribution. Regional Distribution of GEM Listed Companies. 390 companies from 27 provinces and municipalities have been listed on GEM by Dec.31 ${ }^{\text {st }}$ of 2014 . Regional distribution shows that 84 and 61 of them were from Guangdong and Beijing, respectively, accounting for $21.54 \%$ and $15.64 \%$ of all GEM listed companies. 49, 38 and 30 came from Jiangsu, Zhejiang and Shanghai respectively along the southeast coast, accounting for $30 \%$ of the all; while in raised capital scale, Guangdong and Beijing reached the ratio of $22 \%$ and $17 \%$ with 52.511 billion and 40.795 billion respectively and ranked the first two in total raised amount. The southeast coast raised $29 \%$ of the total amount.

Industrial Distribution. We found through the above-mentioned analysis that the industrial distribution, based on the subdivided industries occupied by the current GEM listed companies, is quite "new". Since GEM demands "growth potential" and so on, enterprises complying with the 
requirement of "five news" (new agriculture, new material, new energy, new economy and new service) and "three highs" (high technology, high growth and high added value) are favored more by GEM.

Secondly, IPO companies on GEM are distinguishable because of the high technology. Although GEM has twenty-two industries which are widely distributed, our statistics shows that a majority of enterprises are engaged in high-tech. For example, computer application service and electronic information, with obvious high-tech features, are industrial chain business in the category of or derived from computer application. Besides, it is shown that many companies are distributed over specialized and scientific services, e.g., medicinal \& biological and chemistry \& chemical engineering. The proportions of Chinese herbal medicines and Chinese patent medicine processing and chemical medicine and preparation manufacturing are considerable too.

Equipment manufacture, the highest distributed industry, can be further divided into medical device manufacture, metallic ore commercial plant manufacture, instrument manufacture, communication and related device manufacture, electrical and control equipment manufacture, computer and related equipment manufacture, electron device and apparatus manufacture, etc. Most GEM listed companied distributed in these subdivided industries are high-tech-based. The distribution is characterized by "high-tech". The vast majority of these GEM listed enterprises are identical to the "seven major emerging industries" proposed in the Twelfth Five-year Plan, i.e., high-end machinery manufacturing, new energy, new material, energy-conservation \& environment-protection, new energy automobiles, emerging biological medicines and emerging information business.

\section{Sample Selection, Variable Description and Research Method}

Sample Selection. This paper takes a sample of 340 enterprises and screens them in accordance with the principles below:(a) Select financial data of every full fiscal year, from three years before IPO to Dec. $31^{\text {st }}$ of 2014;(b) Eliminate samples with incomplete or abnormal data; (c) Ensure that all sample data is public, real and complete.

Index Selection and Variable Description. In addition to regional and industrial influence, we pay attention to the business performance and technological innovative ability of enterprises in the analysis on influence factors on enterprises' financing capacity, which has been analyzed from the aspect of asset scale, growth ability, profitability and technological innovative ability.

Table 1 Influence Factors on Enterprise's IPO Financing Capacity

\begin{tabular}{|l|l|l|}
\hline Influence Factor & Index & Measurement standard \\
\hline \multirow{2}{*}{ Size Influence } & Total assets (before IPO) & $\begin{array}{l}\text { Average total assets of the three years } \\
\text { before IPO }\end{array}$ \\
\cline { 2 - 3 } & Total assets (after IPO) & Average total assets after IPO \\
\hline Growth Ability & Main business income & $\begin{array}{l}\text { Average main business income of the three } \\
\text { years before IPO }\end{array}$ \\
\hline Profitability & Retained profits & $\begin{array}{l}\text { Average net margin of the three years } \\
\text { before IPO }\end{array}$ \\
\hline Debt Paying Ability & Asset-liability ratio & $\begin{array}{l}\text { Average asset-liability ratio of the three } \\
\text { years before IPO }\end{array}$ \\
\hline \multirow{3}{*}{ Technological } \\
Innovative Ability & Research expenditure & $\begin{array}{l}\text { Average research expenditure of the three } \\
\text { years before IPO }\end{array}$ \\
\cline { 2 - 3 } & Research expenditure/ total assets & $\begin{array}{l}\text { Research expenditure of the three years } \\
\text { before IPO / average total assets }\end{array}$ \\
\cline { 2 - 3 } & $\begin{array}{l}\text { Research expenditure/ main } \\
\text { business income }\end{array}$ & $\begin{array}{l}\text { Research expenditure of the three years } \\
\text { before IPO / main business income }\end{array}$ \\
\hline
\end{tabular}

Notice: The financial data comes from wind and the patent data comes from the site of SIPO. 
Research Method. Data of 340 samples were imported into vector files by region with ArcGIS 10.2. Edit property sheets and sort rendering to see the distribution of total raised amount nationwide. Classify the samples by industry with EXCEL and make descriptive statistics of different industry samples. Compare the relationships between IPO influence factors and raised funds on graphs. Make principal component analysis on different influence factors and raised funds with IBM SPSS 23 and find out the relationships between different influence factors and raised funds.

\section{Empirical Results and Analysis}

Analysis of Influence Factors on IPO Financing Capacity. Take the compound average of raised funds, average research expenditure, average of main business income, average total assets of the three years before IPO and the internet lot winning rate as studied indexes; select industries with higher proportions as the studied objects.

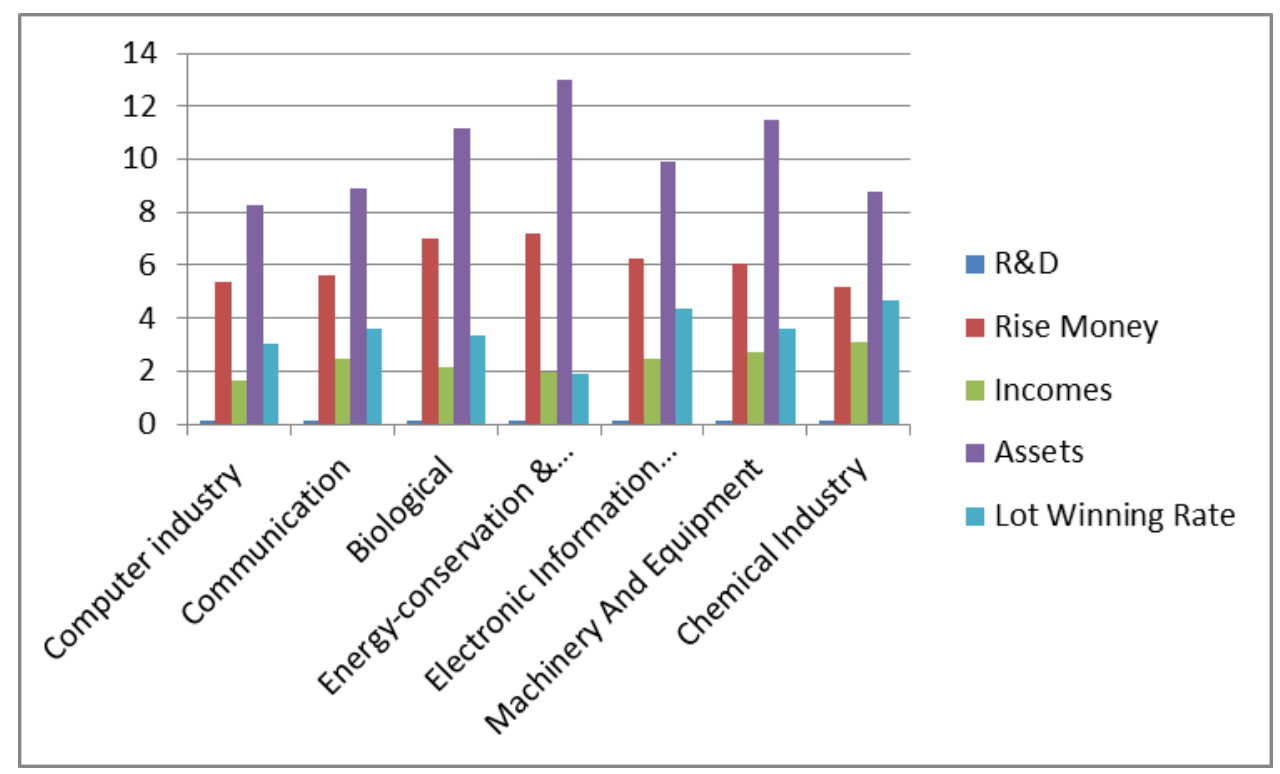

Figure 1. Comparison chart of IPO influence factors, raised funds and lot winning rates of different industries (Unit: Million)

As shown in Fig. 2, industries with larger asset size before IPO, such as energy-conservation \& environment-protection, electrical equipment, biological medicines and machinery, have larger fund-raising numbers in listing financing. Based on the assumption that operation cycle of secondary market has an equal influence on the financing capacity of different companies, the ones with lower internet lot winning rate are more favored by investors. We can see that electrical equipment has the highest lot winning rate, while energy-conservation \& environment-protection has the lowest. Meanwhile, companies engaged in energy-conservation \& environment-protection has lower research expenditures and lower business income. Likewise, we find that owing to the national requirements of promoting new energies and environmental protection industry, enterprises involved in energy conservation and environment protection are more favored by investors on the capital market. But it also can be seen that, environment protection enterprises are in the initial stage at present. As a result, the scientific research inputs are not high while their business incomes are lower compared with the total assets and raised funds. It is expectable that in the structural transformation of the economy of the future, industries of new energy and environment protection will play a more important role and realize their great potential. 
Table 2 Analysis of IPO influence factors and major financing ability constituents

\begin{tabular}{|l|l|l|l|l|l|}
\hline & Constituent & & & \multicolumn{2}{l|}{ Constituent } \\
\hline & 1 & 2 & & 1 & 2 \\
\hline Assets (after IPO) & 0.87 & 0.23 & Net margin & 0.82 & 0.27 \\
\hline Total funds raised & 0.64 & 0.44 & Owner's equity & 0.85 & 0.04 \\
\hline $\begin{array}{l}\text { Internet lot } \\
\text { winning rate }\end{array}$ & 0.29 & 0.09 & Asset-liability ratio & 0.33 & -0.60 \\
\hline $\begin{array}{l}\text { Offline lot } \\
\text { winning rate }\end{array}$ & 0.38 & -0.05 & $\begin{array}{l}\text { Assets (before } \\
\text { IPO) }\end{array}$ & 0.93 & -0.14 \\
\hline $\begin{array}{l}\text { Raised fund/ } \\
\text { assets (after IPO) }\end{array}$ & -0.34 & 0.62 & $\begin{array}{l}\text { Research } \\
\text { expenditure/ assets }\end{array}$ & -0.16 & 0.77 \\
\hline $\begin{array}{l}\text { Research } \\
\text { expenditure }\end{array}$ & 0.71 & 0.40 & $\begin{array}{l}\text { Research } \\
\text { expenditure/ major } \\
\text { business income }\end{array}$ & -0.18 & 0.72 \\
\hline $\begin{array}{l}\text { Major business } \\
\text { income }\end{array}$ & 0.89 & -0.07 & & & \\
\hline
\end{tabular}

\section{Relationship Study between IPO Influence Factors and Financing Capacity.}

KMO and Bartlett test showed that the KMO value was 0.678 , which was above empirical value 0.6; and the significance of Bartlett was 0 , which was lower than the empirical value 0.01. Taken together, it is appropriate to perform principal component analysis on the selected factors hereof.

Table 2 shows that the first principal components include assets (before IPO), assets (after IPO), research expenditure, major business income, net margin, owner's equity and total raised amount. This it can be seen that total raised amount is correlated to assets (before IPO), assets (after IPO), research expenditure, major business income, net margin and owner's equity. We can see that, before IPO, the total raised amount is correlated with the enterprise scale and financial operation. Meanwhile, it is easier for enterprises with stronger technological innovative ability to raise funds required by development.

Second principal components include research expenditure/assets, research expenditure/major business income and raised fund/assets (after IPO). Raised fund/assets (after IPO) represents the expansion coefficient of total assets after IPO. The smaller the value, the greater the expansion is. Analysis shows that raised fund/assets (after IPO) is correlated to research expenditure/assets and research expenditure/major business income. Thus it is known that fund/assets (after IPO) is correlated to enterprise's scientific research and technological innovative ability.

It is found through analysis of the first and second principal components that raised fund is correlated to enterprise scale, financial operation and technological innovative ability, whereas raised fund/assets (after IPO) is correlated to technological innovative ability only. Thus, technological innovative ability becomes the standard measuring financing capacity and is a critical influence factor on the expansion of enterprise scale.

\section{Conclusion}

Based on the statistical integration of 340 companies getting listed in 2009-2013, this paper conducts classification analysis by region and industry. Meanwhile, it concludes assessment indexes to multiple component factors to describe different aspects of influence factors. The following conclusions have been drawn based on the analysis:

Beijing, Guangdong and the southeast coastal region of China are dense districts of innovative high-growth and high-tech enterprises and the highest economically developed. Influenced by local economic development and policy support, enterprises in these areas are more frequently seen on GEM and have stronger financing capacity and more sustained development;

GEM listed companies engaged in the industry of machinery manufacture, medicinal \& 
biological, electronics \& computer technology, communications and energy-conservation \& environment-protection have stronger financing capacity, which is consistent with the basic state policy of the "seven major emerging industries" proposed in the Twelfth Five-year Plan. Affected by future development anticipation, the industry of energy-conservation \& environment-protection has the strongest financing capacity. However, since it is still in the initial stage of development and the input in environment protection and new energies has just started, the business income has great growth potential. As the state increases its requirement of environment protection and new energies, the industrial development is highly worth expecting.

Financing capacity of GEM listed company is closely related to enterprise scale, financial status and technological innovative ability. Before the IPO of a company, investors prefer to predict the corporate development through the asset scale, major business income and net margin. They also take technological innovative ability into account before investing; after IPO, the growth of the total assets becomes influenced by technological innovative ability; likewise, without considering the company scale, the technological innovative ability of a company becomes the standard measuring its financing capacity.

To sum up, this paper believed that it's better for companies with GEM listing potentiality and high-tech enterprises with the demand and willingness of listing financing to pay attention to the analysis results as mentioned above. Enterprises should improve their technological innovative ability while promoting the business operating capacity to lay a solid foundation for the future development.

\section{References}

[1] Berger A, Saunders A, Scalise, J and Udell G F.Does market size structure affect competition? The case of small business lending [J]. Journal of Banking \& Fi -nance, 2007 ( 1): 11 -33.

[2] Xu Xiaoping, Li Xiaojie. Credit Gap and Technical Defects of SMEs and Government Intervention-Based on the 2008 Small Business Survey in Economic Parks of Shanghai [J]. Journal of Shanghai University of Finance and Economics, 2009, (4): 65-72.

[3] Li Yanghui, Ding Min. GEM Market and Financing of New High-tech Enterprises [J]. Economics and Business, 2008 (8): 72-73.

[4] HAROLD DEMSETZ, BELEN VILLALONCA.Ownership structure and corporate performance[j].Journal of Corporate Finance, 2001(7):209-233.

[5] RAMI ZEITUN,GARY GANG TIAN.Capital structure and corporate performance: Evidence from Jordan [J].The Australasian Accounting Business and Finance Journal, 2007, 1(4):40-61.

[6] Sun Linjie, Sun Linzhao. Evaluation Research of Technology-based SEMs' Financing Capacity [J]. Science of Science and Management of S. \&.T, 2007 (5):148.

[7] Huang Junhui, Wang Wanchen. IPO Research of GEM [J]. Research on Financial and Economic Issues, 2001, (12):1-5.

[8] Bernard S. Black, Ronald J. Gilson. Venture Capital And the Structure of Capital Markets:Banks Versus Stock Markets[J].Journal of Financial Economics.1998, 47:243-277.

[9] Adam, T., and V. K. GoyaL 2008. "The Investment Opportunity Set and Its Proxy Variables", journal of Financial Research, 31(I); 41-63.

[10]Su Dongwei. ersification Premium of Chinese Listed Companies. Economics 2005, (4): 135.

[11]ZhaDiversified Operation and Enterprise Value: Empirical Analysis on Diversification Premium of Chinese Listed Companies. Economics 2005, (4): 135.

[12]Zhang Yi, Li Chen. Equity Structure, Cash Flow and Capital Investment. Economics 2005 (4): 229-246.

[13] Wang Hecheng, Meng Yanfen. Study on Competence-based Enterprise Competitiveness [J]. Science Research Management, 2004, 25 (6). 